\title{
Forkhead Box Protein D3
}

National Cancer Institute

\section{Source}

National Cancer Institute. Forkhead Box Protein D3. NCI Thesaurus. Code C92176.

Forkhead box protein D3 (478 aa, $\sim 48 \mathrm{kDa}$ ) is encoded by the human FOXD3 gene. This protein is involved in embryonic development. 